\title{
Atmospheric volatile organic compounds in a Portuguese mountain region
}

\author{
M. Evtyugina ${ }^{1}$, T. Nunes ${ }^{1}$, C. Alves ${ }^{1} \&$ M. C. Marques ${ }^{2}$ \\ ${ }^{I}$ CESAM, Centre for Environmental and Marine Studies, \\ Department of Environment and Planning, Aveiro University, Portugal \\ ${ }^{2}$ University of Trás-os-Montes e Alto Douro, Portugal
}

\begin{abstract}
Ambient air volatile organic compounds (VOCs) samples were simultaneously collected at two sites during two consecutive weeks of June 2006 at Alvão Natural Park, in the north of Portugal, where spring and summer ozone exceedances have been registered over the last years. One of the sites was located at the background air quality monitoring site of Lamas de Olo, in the Alvão Mountain. Other site was sampled on the outskirts of the Park to characterise the predominant upwind air masses associated with higher ozone levels. Stainless steel canister and sorbent tube sampling was performed for the determination of $\mathrm{C}_{2}-\mathrm{C}_{6}$ and $\mathrm{C}_{6}-\mathrm{C}_{11}$ non-methane hydrocarbons, respectively, after analysis by gas chromatography coupled with flame ionisation detection or mass spectrometry.
\end{abstract}

Keywords: VOCs, tropospheric ozone, rural area, PEC.

\section{Introduction}

In the last years, several photochemical episodes have occurred both in urban and suburban sites [1,2] as well in rural areas [3, 4], being related to a set of photochemical reactions between VOCs and $\mathrm{NO}_{\mathrm{x}}$. Tropospheric ozone is a photochemical secondary pollutant of major importance with effects on health, agriculture productivity, natural ecosystems and materials [5-7].

In the past, air quality problems in Portugal were usually focused on urban or important industrial areas, placed mainly along the Atlantic coast. Nevertheless, some studies performed in the last decade showed elevated ozone levels in rural areas far from the anthropogenic source emissions [8-10]. 
High temperature and strong radiation during warm and hot seasons are characteristics that favour photochemical formation of secondary pollutants, such as ozone, in the Portuguese territory. Since the start-up of Lamas de Olo, a rural air quality monitoring station, at an altitude of $950 \mathrm{~m}$ a.s.1., in the Natural Park of Alvão (NPA), the number of ozone exceedences registered in Portugal has increased significantly [11]. In the last five years, the highest ozone levels in Portugal were recorded in this air quality station. This place reached the highest hourly average level in Europe in 2005, with $361 \mu \mathrm{g} \cdot \mathrm{m}^{-3}$ [11]. To explain these high values, it will be crucial to evaluate the concentrations of ozone precursor, like $\mathrm{NO}_{\mathrm{x}}$ and VOCs. In rural areas, biogenic VOCs play an important role in photochemical chemistry affecting ozone production.

Aiming to understand the high levels of ozone in this area, several samplings were performed during last summer (2006) to characterise and quantify the VOCs composition and trying to identify their possible contribution for ozone production.

\section{Experimental}

In the period of 23rd June to 1st July 2006 an air quality monitoring field campaign was performed in NPA in the NE of Portugal at two sites (Figure 1), simultaneously. The first location is situated at an elevated of $500 \mathrm{~m}$ a.s.1. in the Basal Zone of West region of NPA, close to Ermelo village. The second location is situated in the East upper zone of NPA, in Lamas de Olo, coincident with the air quality station of the national network.

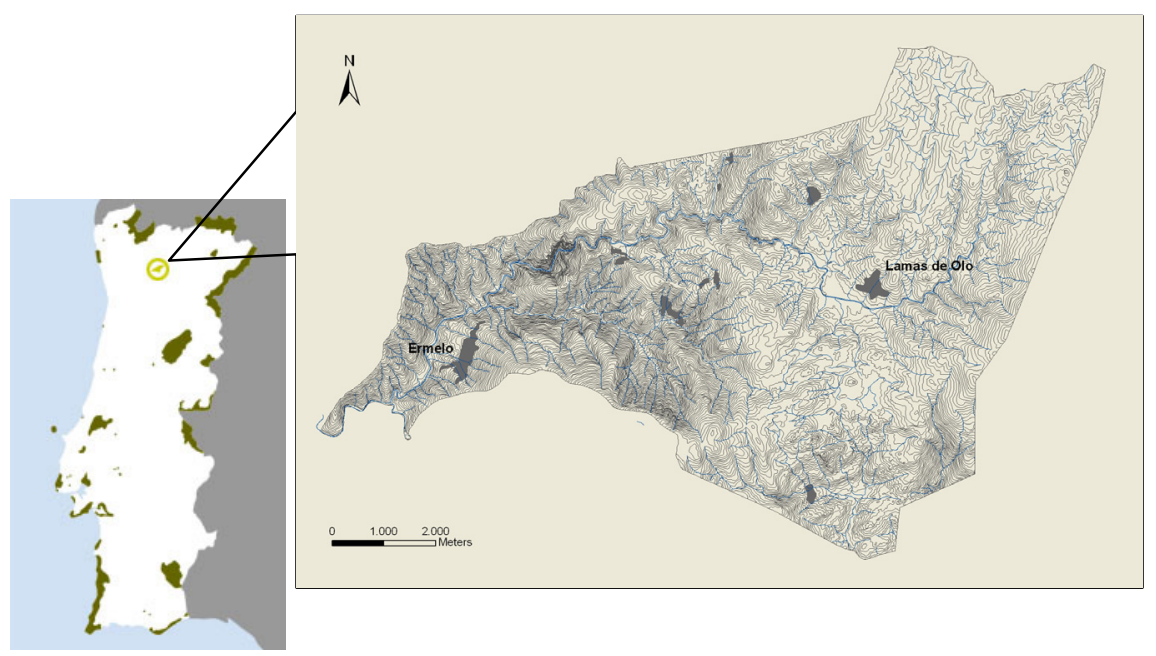

Figure 1: Maps of Portugal and NPA area, where the sampling sites are marked (map of Portugal from www.icn.pt) [12]. 
The upper zone is dominated by large granite blocks, makes the landscape harsh and angular. The Basal Zone, with its narrow enclosed valleys is characterised by schist and by the presence of an abrupt change of altitude. This region benefits from the joint effect of the temperate Mediterranean type climate and the alpine influences (caused by the altitude). The NPA include a large floristic diversity which main species are: Quercus pyrenaica, Quercus robur, Bétula alba and small patch of Quercus suber. The rocky upper zone is dominated by Erica sp., Cytisus striatus, Baccharis trimera, Cistus salvifolius and Ulex parviflorus.

At each location ozone and $\mathrm{NO}_{\mathrm{x}}$ concentrations were monitored continuously with Environment- $\mathrm{O}_{3}$ model $41 \mathrm{M}$ and Environment AC model $42 \mathrm{C}$, respectively. Meteorological parameters were measured with portable meteorological stations equipped with standard sensors. Low VOCs $\left(\mathrm{C}_{2}-\mathrm{C}_{7}\right)$ were sampling using stainless steel canister. Air samples were analysed by GC-FID, Chrompack ${ }^{\circledR} \mathrm{CP}$ 9001, equipped with a specific cryogenic pre-concentration system [13]. The GC-FID analytical conditions were adapted from $J \& W$ Technical Support Ozone Precursor Analysis on GS-Alumina/KCl (http://www.jandw.com).

The heavy VOCs $\left(\mathrm{C}_{5}-\mathrm{C}_{11}\right)$ were collected in a stainless steel tube trap, filled with $120 \mathrm{mg}$ of Tenax-TA (60-80 mesh) and $100 \mathrm{mg}$ of Carbotrap B (60-80 mesh). The samples were desorbed and analysed by thermal desorption cryogenic concentration method using a GC-FID, Chrompack ${ }^{\circledR}$ CP 9000, equipped with a Chrompack Thermal desorption-Cold Trap injection (TCT) [10].

\section{Results}

The temporal variation of the meteorological parameters measured during the sampling campaign at Ermelo and Lamas de Olo is shown in Figure 2.

Highest levels and daily temperature amplitudes were registered at Ermelo. It was also observed that $30^{\text {th }}$ June and $1^{\text {st }}$ July were the hottest days of the sampling campaign. The wind blew predominantly from E, NE and SE in Ermelo, where its speed did not exceed $2 \mathrm{~m} \mathrm{~s}^{-1}$ during daytime, decaying to values close to zero at night. In Lamas de Olo the leading wind directions were from $\mathrm{W}$ and $\mathrm{N}$ with much higher speeds than in Ermelo, especially in the late afternoon and early night. The altitude, low surface roughness and a poor vegetation land cover may explain the stronger winds registered in the upper zone.

Figure 3 depicts the variation of concentrations of $\mathrm{O}_{3}$ and $\mathrm{NO}_{\mathrm{x}}$ monitored in the two sampling sites.

The profile of $\mathrm{O}_{3}$ at the low-altitude site (Ermelo) showed lower values and higher daily amplitudes than those registered at the high-altitude site (Lamas de Olo). The highest ozone levels were registered on $30^{\text {th }}$ June, reaching values of 186 and $223 \mathrm{\mu g} \mathrm{m}^{-3}$ in Ermelo and Lamas de Olo, respectively. Throughout the sampling campaign, relatively high nocturnal levels were registered at these two sites. At the upper zone, nocturnal minima higher than $60 \mu \mathrm{g} \mathrm{m}^{-3}$ were measured, reaching sometimes $\sim 150 \mu \mathrm{g} \mathrm{m}^{-3}$. These high ozone levels during the night-time may be associated with the low $\mathrm{NO}_{\mathrm{x}}$ concentrations observed at both sites due to 
the weak $\mathrm{O}_{3}$ titration by the rapid reaction with NO. Altitudinal differences could also be caused by less vertical mixing. In addition, $\mathrm{O}_{3}$ intrusions with stratospheric origin and reduced loss processes at greater altitudes may explain this phenomenon [14]. Some studies previously performed in mountainous regions of the EU and USA also refer that surface ozone mixing ratios increase with altitude, showing high nocturnal concentrations [14-16].

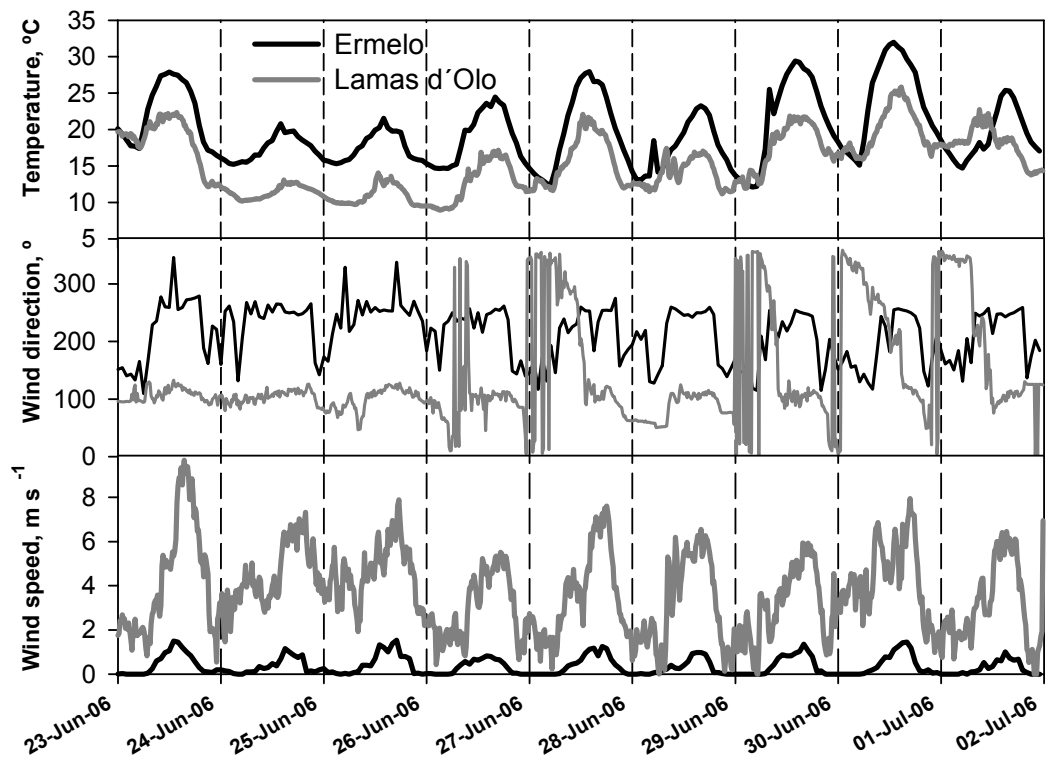

Figure 2: Meteorological parameters from 23rd June and 1st July 2006, at Ermelo and Lamas de Olo.

Throughout the experimental campaign, 30 VOCs were identified whose total concentrations are shown in Figure 4.

In general, the total VOC levels were lower in the upper zone than at the lowaltitude site. At Lamas de Olo, the VOC concentrations did not exceed for the whole measuring period, excepting $30^{\text {th }}$ June. Usually, at the basal zone, the $\mathrm{C}_{5^{-}}$ $\mathrm{C}_{11}$ VOCs showed higher levels than those of the upper zone. However, on $30^{\text {th }}$ June, the station at greatest altitude registered a huge increase in low VOC concentrations. Since the majority of these compounds present low photochemical reactivity and a long residence time, an increase in their concentrations may reflect the influence of atmospheric transport on a synoptic scale. This hypothesis is confirmed after applying the HYSPLIT (Hydrid SingleParticle Lagrangian Integrated Trajectory Model) model to the upper zone. A dynamic analysis showed that the transport of marine air masses from $\mathrm{N}$ and $\mathrm{NE}$ of the Iberian Peninsula was prevalent throughout the sampling period. On $30^{\text {th }}$ June, polluted continental air masses coming from the south of Portugal 
(backward trajectories at final height of $1000 \mathrm{~m}$ ) reached the upper zone, whereas air masses (computed at a final height of $500 \mathrm{~m}$ ) arrived at the north of the Iberian Peninsula after following exclusively an oceanic trajectory. Thus, both stations were affected by different air masses, which may explain the sudden enrichment in low VOCs observed in Lamas de Olo.

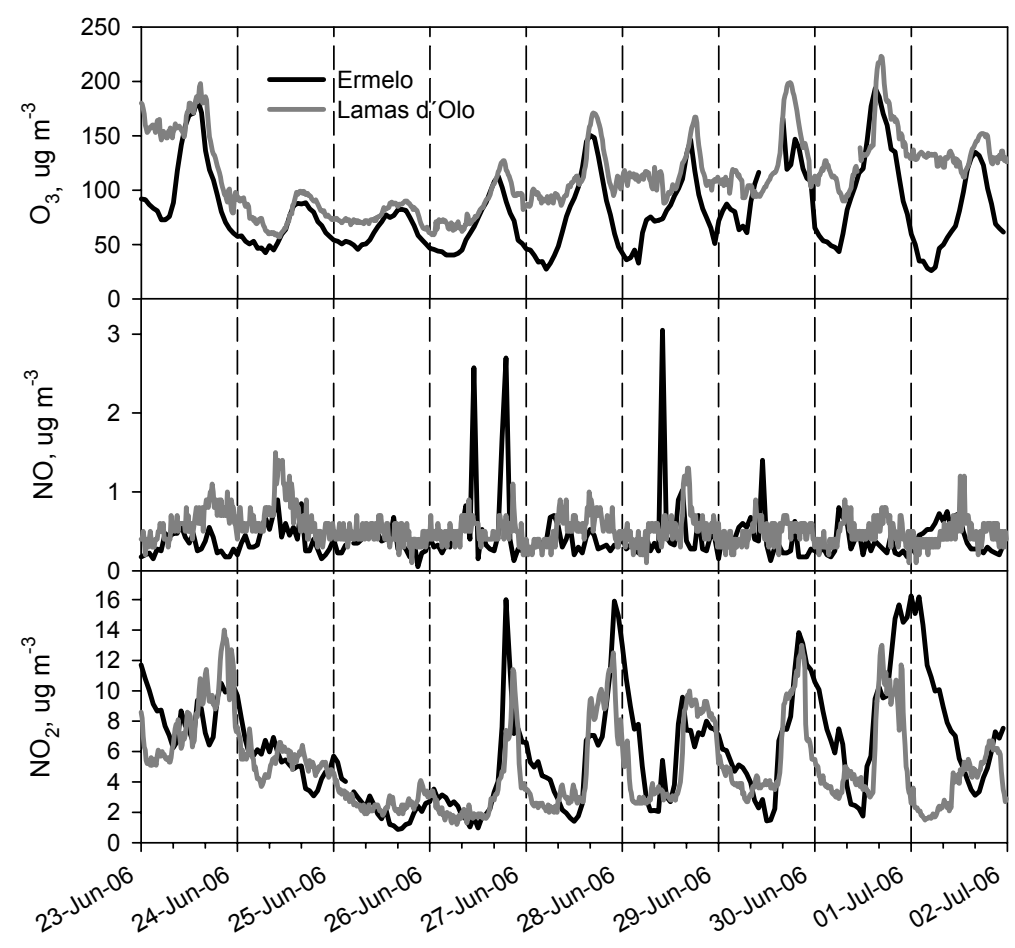

Figure 3: Comparative variation in concentrations of $\mathrm{O}_{3}, \mathrm{NO}$ and $\mathrm{NO}_{2}$ in Ermelo and Lamas de Olo throughout the study period.

In order to evaluate the possible contribution of individual VOCs to the photochemical production of ozone, the Propylene Equivalent Concentration (PEC) was determined [17]. In this calculation, the average concentration of the different low and heavy VOCs measured at both stations, as well the own kinetic constants for the reaction with the $\mathrm{OH}$ radical $[18,19]$ were used.

Figures 5 and 6 depict the average concentrations of low and heavy VOCs and respective PEC. The basal zone is the one with the highest equivalent concentration for both low and heavy VOCs. It was also concluded that compounds of biogenic origin (isoprene and monoterpenes) represented a much higher potential to produce ground ozone than that of other some compounds with higher concentrations. 


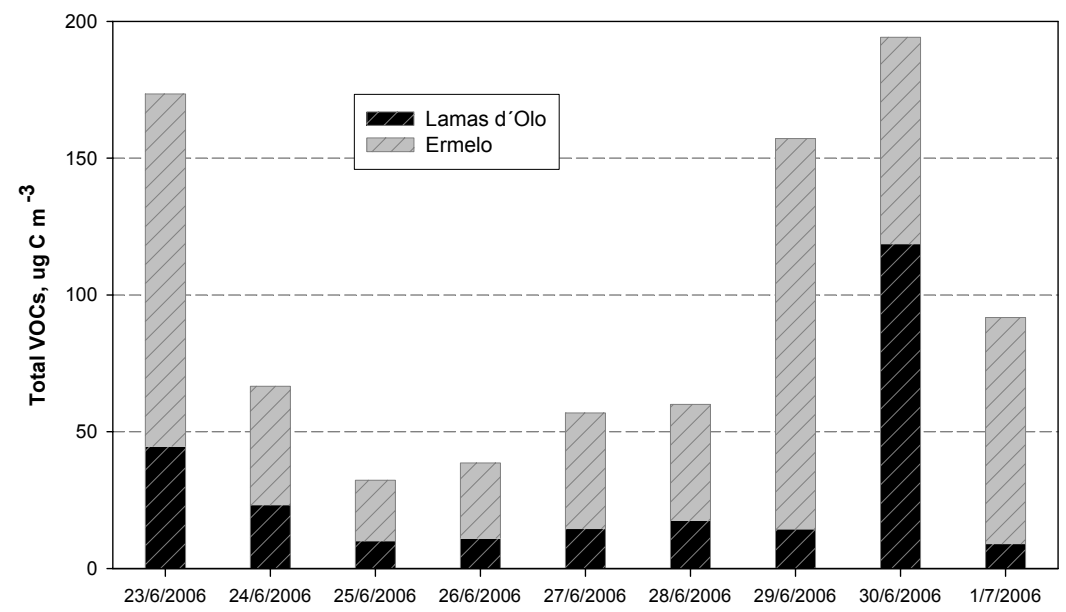

Figure 4: $\quad$ Total VOC concentrations measured in Ermelo and Lamas de Olo.

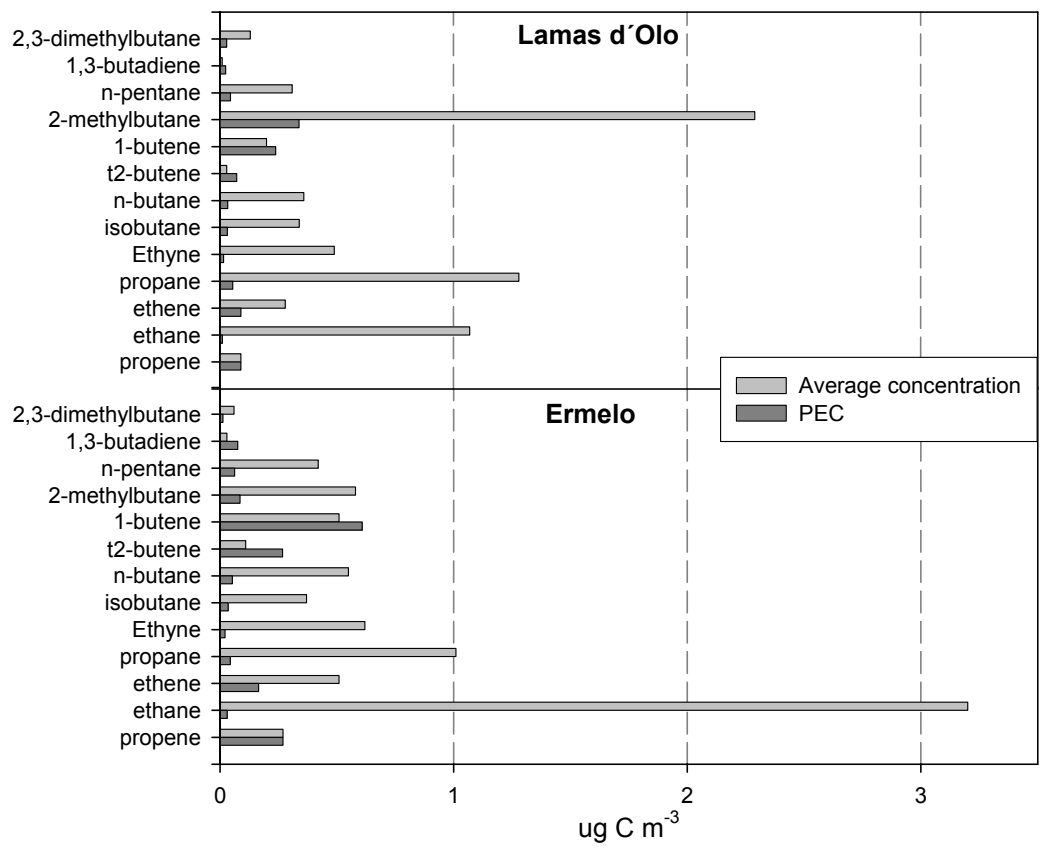

Figure 5: Average concentration and PEC of VOCs, $\mathrm{C}_{2}-\mathrm{C}_{7}$, between 23rd June and 1st July 2006. 


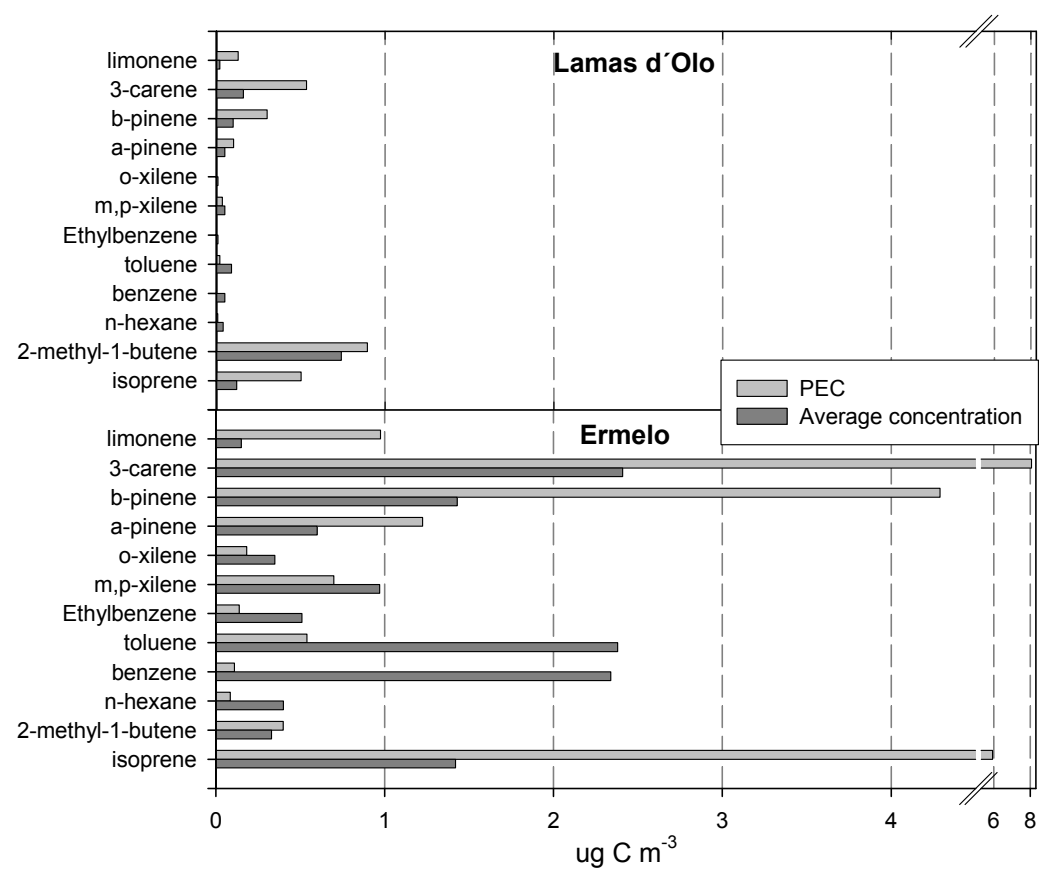

Figure 6: Average concentration and PEC of VOCs, $\mathrm{C}_{5}-\mathrm{C}_{11}$, between 23rd June and 1st July 2006.

\section{Conclusions}

The upper zone presented higher ozone levels that those registered at the lowaltitude site. The low $\mathrm{NO}_{\mathrm{x}}$ concentrations observed in both sites may be associated with the weak titration of $\mathrm{O}_{3}$ by the reaction with $\mathrm{NO}$, directly contributing to the low ozone consumption during the night-time period. In general, the total VOC concentrations were higher at the basal zone. The PEC calculation showed an important contribution of biogenic compounds (e.g. 3-carene, isoprene and $\beta$-pinene) to the photochemical production of ozone, especially at the basal zone of the natural park. In a near future, this information would be somehow important when developing a photochemical transport model to simulate the ozone formation in this region.

\section{Acknowledgements}

We thank Fundação para a Ciência e a Tecnologia for the financial support through the project FOTONET (GG/GGP/ME611-0165/05), as well as the PostDoc grant to M. Evtyugina. 


\section{References}

[1] Zhang, B. N. \& Oanh, M.T.K. Photochemical smog pollution in the Bangkok Metropolitan Region of Thailand in relation to O3 precursor concentration and meteorological conditions. Atmospheric Environment 36, 2002, pp. 4211-4222.

[2] Klemm, O., Zoimas, I.C., Balis; D., Suppan, P., Slemr, J., Romero, R. \& Vyras, L.G., A summer air-pollution study in Athens, Greece. Atmospheric Environment, 32, 1998, pp. 2071-2087.

[3] Dueñas, C., Fernández, C.M., Cañete, S., Carretero, J. \& Liger, E., Analyses of ozone in urban and rural sites in Málaga (Spain). Chemosphere, 56, 2004, pp. 631-639.

[4] Donev, E., Zeller, K. \& Avramov, A., Preliminary background ozone concentrations in the mountain and coastal areas of Bulgaria. Environmental Pollution, 117, 2002, pp. 281-286.

[5] Ozen, B.F., Mauer, L.J. \& Floros, I.D., Effects of ozone exposure on the structural, mechanical and barrier properties of select plastic packaging film. Packaging Technology and Science, 15, 2002, pp. 301-311.

[6] Brauer, M. \& Brook, J.R., Ozone personal exposure and health effect for selected groups residing in the Fraser Valley. Atmospheric Environment, 31, 1997, pp. 2113-2121.

[7] Hogsett, W.E., Weber, J.E., Tingey, D.T., Herstrom, A.A., Lee, E.H. \& Laurence, J.A., An approach for characterizing tropospheric ozone risk to forests. Environmental Management, 21, 1997, pp. 105-120.

[8] Bonsang, B., Moortgat, G.K. \& Pio, C.A., Overview of the FIELDVOC'94 experiment in a eucalyptus forest of Portugal. Chemosphere, 3, 2001, pp. 211-226.

[9] Harder, H., Pätz, W., Volz-Thomas, A., Fischer, H. \& Zenkes, T., Measurements of nitrogen oxides, ozone, and carbon monoxide during the FIELDVOC'94 campaign in Tábua. Chemosphere, 3, 2001, pp. 227-237.

[10] Evtyugina, M.G., Nunes, T., Pio, C.A. \& Costa C.S., Photochemical pollution under sea breeze conditions, during summer, at the Portuguese West Coast. Atmospheric Environment, 33, 2006, pp. 6277-6293.

[11] IA (2003), (2005), (2006). (http://www.qualar.org).

[12] ICN/UA, Plano de Ordenamneto do Parque Natural do Alvão, 2006.

[13] Pio, C., Duarte, A.C., Nunes, T., Gomes, P. \& Matos, J., Biogenic and anthropogenic contribution to ambient volatile organic compounds (VOV14), Appendix III, Final Report, Determination of anthropogenic and biogenic contribution to ambient volatile organic carbons, Report available at Netherlands Energy Research Foundation, 1998, Netherlands.

[14] Ribas, A. \& Peñuelas, J., Surface ozone mixing ratio increase with altitude in a transect in the Catalan Pyrenees. Atmospheric Environment, 40, 2006, pp. 7308-7315.

[15] Bytherowicz, A., Godzik, B., Fraczek, W., Grodzinska, K., Frywult, M., Badea, O., Barancock, P., Blum, O., Cerny, M., Godzik, C., Mankovska, B., Manning, W., Moravcik, K.P., Musselmann, R., Oszlanyi, J., 
Postelnicu, D., Szdzuj, J., Varsavova, M. \& Zota, M., Distribution of ozone and other air pollutants in forests of the Carpathian Mountains in central Europe. Atmospheric Environment, 116, 2002, pp. 3-25.

[16] Cooper, S.M. \& Peterson, D.L., Spatial distribution of tropospheric ozone in western, Washington, USA. Environmental Pollution, 107, 2000, pp. 339-347.

[17] Lawrimore, J.H., Das, M. \& Aneja, V.P., Vertical sampling and analysis of nonmethane hydrocarbons for ozone control in urban North Carolina. Journal of Geophysical Research, 100, 1995, 22,785-22,793.

[18] Atkinson, R., Gas-phase tropospheric chemistry of organic compounds. Journal Physical Chemical Reference Data, Monograph 2, 1994, pp 1-216.

[19] Warneck, P., Volatile hydrocarbons and halocarbons (Chapter 6). Chemistry of the Natural Atmosphere. Volume 71, $2^{\text {nd }}$, International Geophysics, Academic Press, San Diego, California. 2000. 